\title{
Social Media in Operations and Supply Chain Management: A Systematic Literature Review to Explore the Future
}

\author{
Yashoda Devi \\ Indian Institute of Management, \\ Kashipur, India, 244713 \\ E-mail: yashoda.fpm1715@iimkashipur.ac.in (Corresponding Author) \\ Kunal K. Ganguly \\ Indian Institute of Management, \\ Kashipur, India, 244713 \\ E-mail: kunal.ganguly@iimkashipur.ac.in
}

\begin{abstract}
Increased use of social media (SM) has led to the generation of a huge quantity of data. Businesses are increasingly using the SM platforms and the data generated on these platforms in area of marketing, co-creation, and customer involvement. However, the contribution of $\mathrm{SM}$ in operations and supply chain management (OSCM) context is still not clear. The aim of this study is to perform an extant literature review of $S M$ in the OSCM context and highlight the applications, methods, and future of SM in OSCM. Systematic literature review approach has been adopted in this study to organize, analyze, and synthesize the existing literature. The results highlight that the disruptive potential of SM has not been fully realized by the OSCM practitioners and researchers and hence the area of SM-OSCM integration is in the nascent stage. Further, the study sheds light on the current applications of SM in OSCM, underlines tools and techniques used by the researchers, and propose future research direction. The study outlines SM characteristics and examples of SM applications in OSCM field. Thus, giving insights to the practitioners and emphasizing the need to incorporate SM to improve OSCM performance. To the best of our knowledge, this study is the first attempt to analyze the existing literature in the intersection of SM-OSCM, and highlight the significance of incorporating $S M$ in OSCM to improve OSCM performance.
\end{abstract}

Keywords: social media, operations management, supply chain management (SCM), systematic literature review (SLR).

\section{INTRODUCTION}

The study presents insights from a systematic review of literature on the use of social media (SM) in operations and supply chain management (OSCM). In the era of digitalization, the use of SM has become ubiquitous in individuals' lives as users create content, express their preferences, and their purchasing behaviour is influenced by the content on social media (Jeble et al., 2017). Acknowledging this, businesses are increasingly using SM platforms in all possible ways (Cui et al., 2018). Exploiting the potential of SM is observed in different fields such as marketing (Cooke and Buckley, 2008), the involvement of customer in product or service discussions (Giannakis et al., 2020), entrepreneurship (Kapoor et al., 2018), innovation and co-creation (Bhimani et al., 2019 and Rathore et al., 2016) and learning and knowledge sharing (Nguyen et al., 2015). Further, the quality management principle of listening to the customer is well supported by SM platforms (Lam et $a l ., 2016)$. The quick flow of information from customer interaction and feedback is vital for business success. However, some practitioners have stressed on the challenges in terms of employee burnout and the firm's competitive disadvantage due to unrestricted knowledge sharing on external social networks. This also has got attention by researchers while integrating SM in OSCM (Leonardi et al., 2013; Lam et al., 2016). On the other hand, the SM's contribution to OSCM is still not clear (Cui et al., 2018).

$\mathrm{SM}$ has grown to be a famous buzzword at both customer and company level, which has transformed the way humans and businesses communicate with each other (Kietzmann et al., 2011). Initially, there was a lot of discussion on the definition of SM (Constantinides and Fountain, 2008), resulting in multiple definitions of SM. McAfee (2009) define SM as "software represented by a range of emerging tools (wikis, blogs etc.) and platform where users are able to share information, and importantly collaborate and create networks or communities". Kaplan and Haenlein (2010) described it as "a group of internetbased applications that build on the ideological and technological foundation of web 2.0, and allow that the creation and exchange of user-generated content". Carlo Bertot et al. (2012) stated that SM is "a set of online tools designed and centred for social interaction". Gupta and Brooks (2013) elucidated social media as "all devices and platform that users use globally to virtually create and share information with each other". Jabeur et al. (2018) defined social media as fundamentally electrical communication procedures through which users can make online communities and share thoughts, feelings, information, messages and other content forms in diverse formats, including text, pictures and videos. Despite multiple 
definitions and diversity in the functionality and use of various SM platforms, the consensus is found on the characteristics that, it provides platform for media sharing (Instagram and YouTube), commerce communities (Amazon and E-bay), networking (LinkedIn and Facebook), blogging, and collaborative sites (Wikipedia) (Rathore et al., 2017). Recently, SM has shifted to mobile phones (Salo, 2017), such as microblogs (e.g. Twitter), and others designed to internal networks (Line, WhatsApp). These SM channels influence individuals' actions based on their usability (Rathore et al., 2017). In the context of OSCM, the SM platform can be used for new product development (NPD) (Irani et al., 2017), to communicate the information such as aid distribution and evacuation routes in case of disaster relief organizations (Yan and Pedraza-Martinez, 2019). Other examples include service improvement (Fan and Niu, 2016), daily sales forecasts (Cui et al., 2018) and information diffusion (Kanagarajoo et al., 2019).

Increase in the use of SM has subsequently led to usergenerated data. Several analytical approaches such as visualization, text mining, network analysis, pattern analysis and influential analysis are used to obtain outcomes on customers' values, sentiments, perspectives and behaviour (Rathore et al., 2017). Numerous organizations opine that customer interaction through SM is essential for delivering solutions that best meet customer needs (Lin et al., 2014). With the increase in the use of SM, there is a need of extant literature review providing a holistic picture of the existing literature on SM-OSCM intersection (Cui et al., 2018). Hence, this study aims to address this gap. To the best of our knowledge, no past research has performed a literature review elucidating the use of SM in the field of OSCM. Thus, a systematic literature review (SLR) is carried-out to shed light on the topic.

This study aims to answer the following research questions

RQ1. What are the contexts of application of SM in OSCM?

$\boldsymbol{R Q 2}$. What are the various research methods and analysis techniques employed by the researchers on the topic?

\section{RQ3. What is the future of SM in OSCM?}

The study aims to contribute to the literature and provide future research directions to the scholars interested in advancing research in SM-OSCM integration. Additionally, the study aims to highlight practical implications for practitioners interested in gaining an indepth understanding of the application of SM in OSCM.

The rest of the study is organized as follows. The methodology used to perform the SLR is presented in detail in section 2. This is followed by the results of the study that are reported and discussed in section 3. Future research avenues in SM-OSCM are presented in section 4. Practical and theoretical implications are highlighted in section 5. Finally, the study is concluded in section 6.

\section{METHODOLOGY}

An SLR has been performed in the current study. SLR is a structured, transparent and reproducible review method which follows specified and documented procedure (Gough et al., 2012). SLR aims to describe existing evidence, specify research gaps, and highlight directions for future research, thus identifying the current scenario in the emerging or established research field (Petticrew and Roberts, 2006;
Huddiniah and ER, 2019). SLR originated in the medical research field (Cochrane Library, 2018), successively adopted by various research domains where a comprehensive review can contribute explicit knowledge (Briner and Denyer, 2012). It differs from the narrative and other nonsystematic literature reviews or expert reviews through its emphasis on transparency and rigorousness (Gough et al., 2012). It also confirms that no relevant research escape through overlook or a known exclusion on an unexplained basis (Pereira et al., 2014). Thus, SLR is a suitable approach for uncovering the existing literature on SM-OSCM intersection, which is an emerging young field. Further, recent literature reviews by Abidi et al. (2014), Dubey and Ali (2015), Thomé et al. (2016), Dubey et al. (2017), Bastas and Liyanage (2018), Friday et al. (2018), Kamble et al. (2020) adopted SLR approach in OSCM context. Hence, in this study, we have adopted the SLR approach and follow the steps proposed by Tranfield et al. (2003), Denyer and Tranfield (2009) and Behera et al. (2019). The review process has been broadly classified into three stages, namely (1) Planning the review, (2) Performing the review and (3) Reporting the review outcomes (Figure 1).

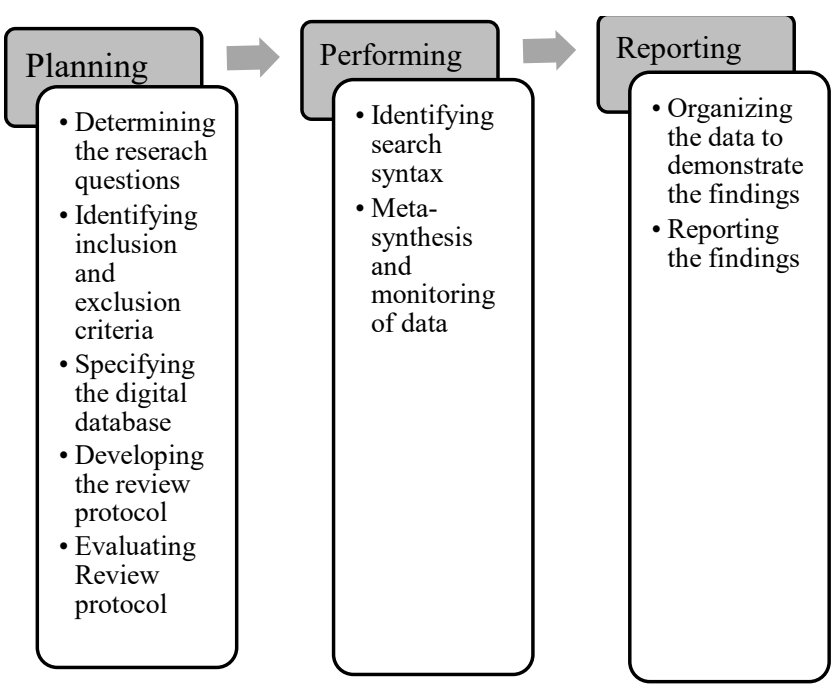

Figure 1 SLR Methodology: Planning, Performing and Reporting [Adapted from Behera et al., 2019]

\subsection{Planning the Review}

This stage has been further subdivided into five steps (see Figure 1).

\subsubsection{Determining the research questions}

Planning of the review starts with the identification of research questions for guiding the study. The existing literature on SM-OSCM intersection is collected to gain insights on the application, methods and analysis techniques, and future of SM in OSCM. Comprehensive details of the SM-OSCM area can be accomplished by investigating the above-mentioned research questions.

\subsubsection{Identifying inclusion and exclusion criteria}

Inclusion criteria (IC) and exclusion criteria (EC) are used to make the data collection process more appropriate. Six inclusion and three exclusion criteria were identified to include/exclude the existing article from the review. The inclusion and exclusion criteria considered in the study are shown in Table 1. 


\subsubsection{Specifying the Digital Database}

The articles considered for review in this study are collected using the online repositories including Scopus, Emerald, Springer, Sage, Wiley online library, JSTOR, Taylor \& Francis, Science direct and IEEE Xplore. Scopus is one of the largest and broadly used database for searching existing literature (Abrizah et al., 2013; Mongeon and PaulHus, 2016). It stores a wide variety of scientific papers and provides access to several high-quality journals (Centobelli et al., 2018). Furthermore, this database has been widely used to produce SLR articles in the areas of OSCM (MorenoCamacho et al., 2019; Govindan and Hasanagic, 2018; Centobelli et al., 2018; Chen et al., 2017; Cerchione and Esposito, 2016). Additionally, other leading databases including Emerald, Science Direct, Wiley online library, Springers, Sage, IEEE Xplore, Taylor Francis and JSTOR, were used. The primary purpose of using various databases is to make the search and collection of papers extremely comprehensive and reliable and include full relevant research articles.

Table 1 Inclusion and exclusion criteria

\begin{tabular}{l}
\hline Inclusion criteria (IC) \\
\hline IC1: Used keywords: "social \\
media" AND ("supply chain" \\
"logistics" OR "procurement" \\
"operations" OR "inventory" \\
"manufacturing") \\
IC2: Research articles pub \\
until October 2020 \\
IC3: Articles written in the \\
English language
\end{tabular}

IC4: Full-text-based studies; used keywords are present in title/abstract/author keywords IC5: Published in peer-reviewed journals IC6: Research article, review article, conference proceeding and article in press

\subsubsection{Developing the review protocol}

Review protocol is specified to provide information regarding the search strategy used to identify relevant studies based on the inclusion and exclusion criteria (Davies and Crombie, 1998). Firstly, the databases (Scopus, Emerald, Science Direct, Wiley online library, Springers, Sage, IEEE Xplore, Taylor Francis and JSTOR databases) are browsed for the published articles to include relevant studies. Secondly, citation chaining was performed to include articles matching the aim of this study but was not found in the above-mentioned databases. Both forward and backward chaining is performed to ensure that all the relevant papers are included in the study.

\subsubsection{Evaluating Review protocol}

To support the data search process, it is essential to assess and evaluate the quality of selected studies. Indeed, the purpose of quality assessment is to make sure that the results of the study are acceptable and unbiased (Ouhbi et al., 2015). Thus, quality evaluation (QE) questions are identified to improve the study. Five QE questions have been designed to advance the scope of the study. These were: QE1: Whether the paper considered for review explicitly mentions the type of analysis technique used. The expected answers are: "quantitative $(+2)$ ", "qualitative $(+1.5)$ ", and "no evidence $(+0)$ "; QE2: Whether the paper explicitly evaluated the challenges and benefits? The expected answers are: "yes $(+2)$ ", "no (+0)" and "partial (+1)"; QE3: Whether outcomes of the paper are justifiable? The expected answers are: "yes $(+2)$ ", "partial (+1)", and "no (+0)". The score is taken partial if the techniques are not described in detail; QE4: Whether the paper is published in a reputed source. The expected answers are: +2 if the sum of citation number and $\mathrm{H}$ index is higher than $100,+1.5$ if the summation of citation number and $\mathrm{H}$ index is in between 50 and $100,+1$ if the summation of citation number and $\mathrm{H}$ index is lying between 1 and 49, and +0 if the summation of citation number and $\mathrm{H}$ index is 0; and QE5: Whether suggested method in the paper is compared with other methods? And the expected answers are: "yes +1 " and "no +0 ".

The quality score has been taken as exclusion criteria i.e., EC3, the studies that meet at least $50 \%$ or more of 9 score, which is ideal, are selected for this review. Citation number and $\mathrm{H}$ index of selected studies are compiled in the Table A1 of Appendix A, which were used to calculate the quality score of the selected studies. Table A2 in Appendix A presents the quality score of selected studies and compositions of evaluation questions. Figure 2, shows the article selection process at different stages. Further, it also highlights the inclusion and exclusion criteria considered at each stage of the article selection process.

\subsection{Performing the Review}

\subsubsection{Identification of Search Syntax}

The syntax used to search published articles in the different database are shown in Table 2. Both "AND" and "OR" Boolean operator were utilized while browsing the databases. The "AND" operator when used between two keywords ensure that both keywords are included in the search term and "OR" operator between two keywords means at-least one keyword should be present in search results. In Scopus, "TITLE-ABS-KEY" search syntax represents that the terms/words are searched in the title, abstract and authors keywords of the research paper. LIMITTO (LANGUAGE, "English") illustrates that the research article should be written in the English language. LIMITTO(DOCTYPE) indicates journal articles are considered for this SLR. Here, "ar" stand for the article in the journal, "cp" shows conference papers and "re" stands for review articles. In Science Direct, the identified keywords were searched in title, abstract and keywords, and the results were limited to "research articles". In JSTOR the specified keywords were searched in all fields; the results were limited to "articles", and the language of published articles was restricted to English. While in rest of the databases, the search was performed in all fields. The search syntaxes used for each 
database can be seen in Table 2. With respect to keywords procurement, logistics, manufacturing, inventory, transportation, operations management are most frequently used words in OSCM reviews (Quieroz et al., 2019; MorenoCamacho et al., 2019).

\subsubsection{Meta-synthesis and Monitoring of Data}

The meta-synthesis technique employs linear search procedure, citation chaining, inclusion and exclusion criteria to obtain a thorough understanding of purpose, methods, applications, outcomes, benefits, and limitations of the articles considered for review. The first step of metasynthesis technique is to perform a linear search in the identified databases using identified keywords. The linear search process resulted in a total of 10123 studies, out of which 2897 from Scopus, 220 from Emerald, 2757 from
Springer, 453 form the Science Direct, 1211 from the Taylor \& Francis, 203 from JSTOR, 860 from Wiley, 1224 form Sage and 298 from IEEE Xplore. This step is followed by the use of the filtration process, i.e., considering the published article for review based on the inclusion and exclusion criteria listed in Table 1. This step is followed by citation chaining, which is again followed by the filtration process. The filtration process which includes inclusion and exclusion criteria is an iterative process, every research paper is checked on the basis of these criteria, the iteration ends when the final list of articles to be considered for the review is obtained. The end of meta-synthesis resulted in fifty-one (51) articles, which are shown in Table A1 of Appendix A, and their bibliographic details can be found in the reference section.

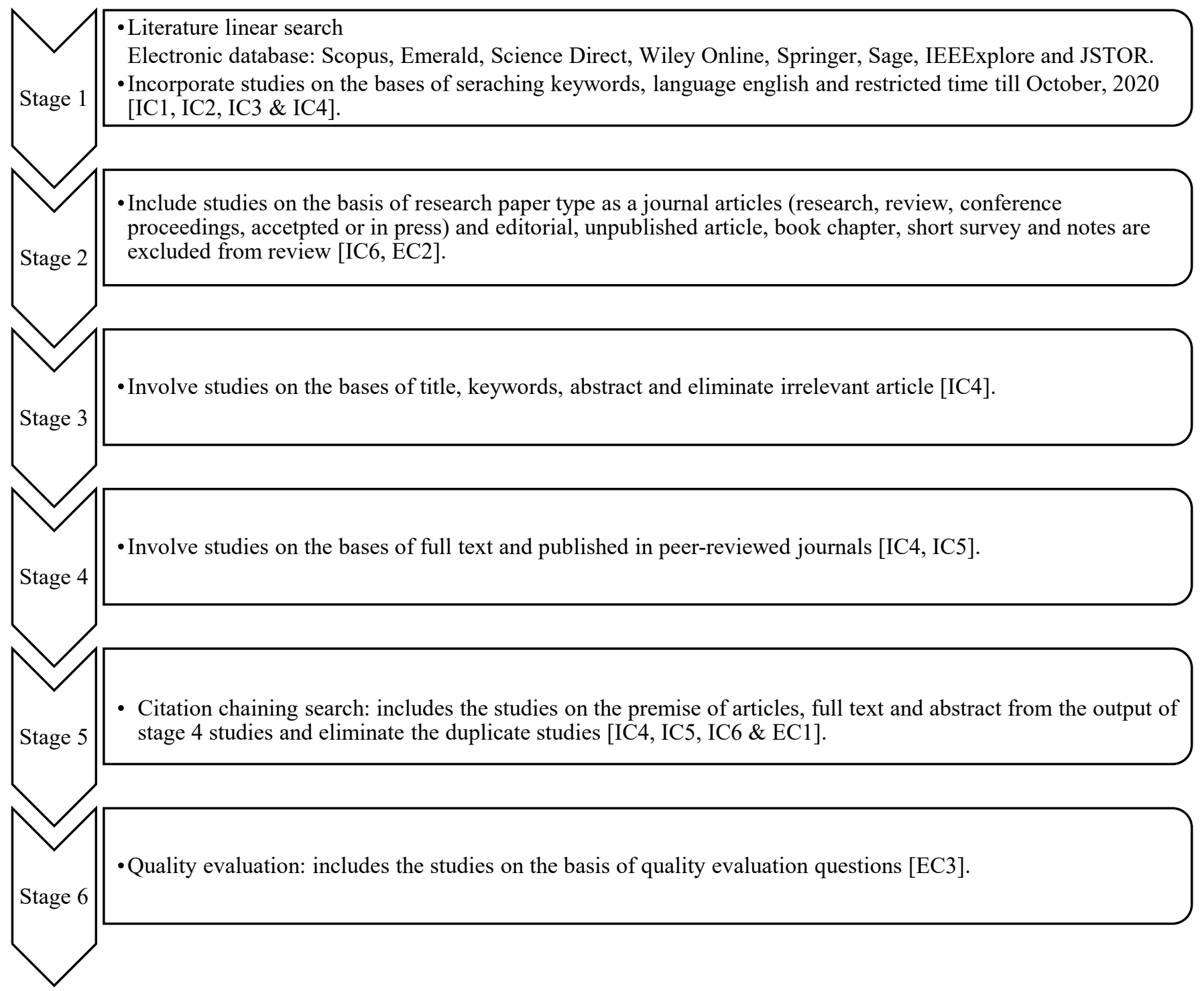

Figure 2 Review protocol and article selection process 
Table 2 Identifying the search syntax

\begin{tabular}{|c|c|}
\hline Digital Databases & Search syntax \\
\hline Scopus & $\begin{array}{l}\text { TITLE-ABS-KEY (("social media" AND } \\
\text { ("supply chain" OR "logistics" OR } \\
\text { "procurement" OR "operations" OR } \\
\text { "inventory" OR "manufacturing"))) AND } \\
\text { (LIMIT-TO (DOCTYPE, "ar") OR LIMIT- } \\
\text { TO (DOCTYPE, "cp") OR LIMIT-TO } \\
\text { (DOCTYPE, "re")) AND (LIMIT-TO } \\
\text { (LANGUAGE, "English")) }\end{array}$ \\
\hline Science Direct & $\begin{array}{l}\text { Title, abstract, keywords: "social media" } \\
\text { AND ("supply chain" OR "logistics" OR } \\
\text { "procurement" OR "operations" OR } \\
\text { "inventory" OR "manufacturing") } \\
\text { Limit to: Research articles }\end{array}$ \\
\hline JSTOR & $\begin{array}{l}\text { "social media" AND ("supply chain" OR } \\
\text { "logistics" OR "procurement" OR } \\
\text { "operations" OR "inventory" OR } \\
\text { "manufacturing") } \\
\text { Limit to: Articles } \\
\text { Limit to: Language - English } \\
\end{array}$ \\
\hline $\begin{array}{l}\text { Emerald, Taylor Francis, } \\
\text { Springer link, Wiley Online } \\
\text { Library, Sage }\end{array}$ & $\begin{array}{l}\text { "social media" AND ("supply chain" OR } \\
\text { "logistics" OR "procurement" OR } \\
\text { "operations" OR "inventory" } \\
\text { "manufacturing") } \\
\end{array}$ \\
\hline
\end{tabular}

\subsection{Reporting the Review}

\subsubsection{Data Organization to Disseminate the Findings}

The extensive search process and stringent inclusion and exclusion criteria, including manual checking of articles to remove duplicate articles and avoid redundancy resulted in fifty-one research papers that match the objective of this study. These fifty-one articles considered for review were organized, visualized, classified, and analyzed to disseminate the findings.

\subsubsection{Reporting the Findings}

The final step of the review process is to report the findings of the review, this could also involve the use of visualization techniques. The word cloud based on the "author keywords" and "article title" of the selected studies are shown in Figure 3(a) and Figure 3(b). From Figure 3(a) and 3(b), it is evident that Social media, supply chain, and operations are the most frequently used words in both author keywords and article title. This shows that the articles considered for the review are relevant to the objective of this study. Other frequently occurring keywords include performance, analytics, customer, knowledge and twitter. Additionally, the study reports the statistical dimensions of data calculated in terms of the number of publications by year, papers published by country, documents published by journals/conferences, and employed research methods in the reviewed studies, which are discussed in the next section. Moreover, we provide insights into the application of SM in OSCM for practitioners and researches interested in gaining a deeper understanding of the topic.

\section{FINDINGS AND DISCUSSION}

\subsection{Number of Publications by Year}

As it is evident from Figure 4, the literature on SMOSCM intersection is not very old. The first article on the topic appeared in the year 2011. Only one research article was published in the year 2011, and one in 2012. three articles were published in 2013, four in 2014, two in 2015, three in 2016, six in 2017, seven in 2018, thirteen in 2019, and eleven in 2020 (till October). This highlights that as the use of SM is increasing, the likelihood of businesses using SM for improving OSCM performance is high. Earlier, the literature focused on highlighting potential application areas of SM information in OSCM. Whereas, in recent years, the literature is majorly focused on the use and effects of SM in decision making, across industries.

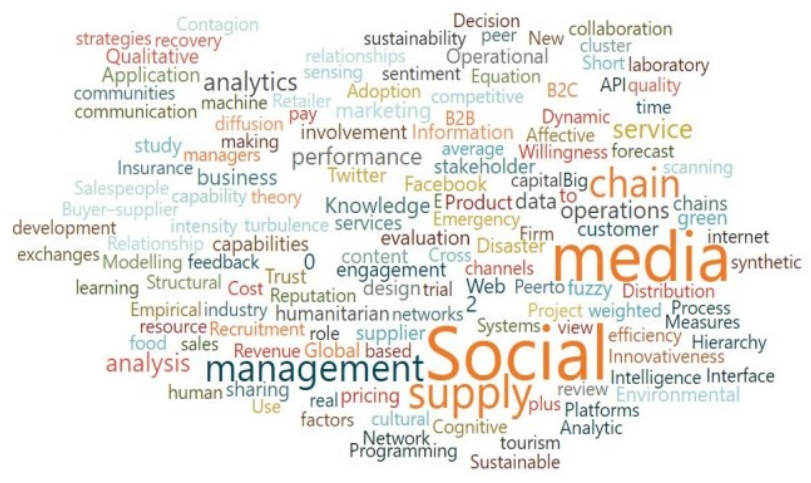

Figure 3(a) Word cloud based on author keywords

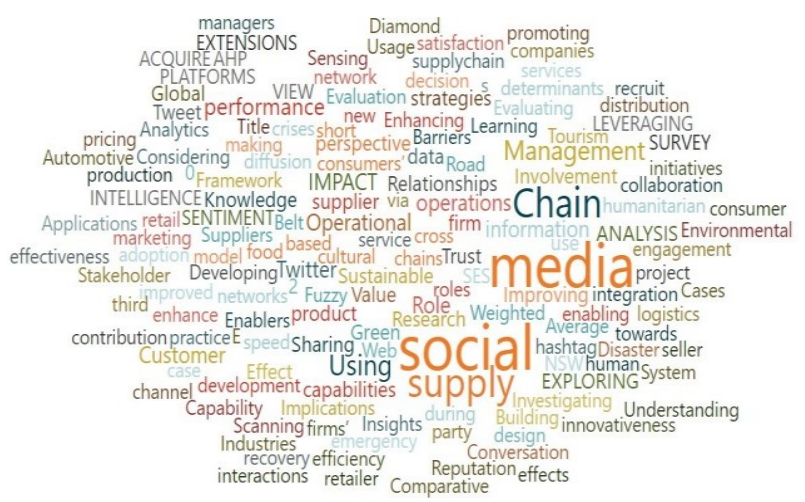

Figure 3(b) Word cloud based on the title of the article

\subsection{Papers Published by The Country}

United States of America (USA) has the highest number of papers published on SM and OSCM intersection (Figure 5). This may be because USA is a leading country in terms of investment on Industry 4.0 (Queiroz et al., 2019), which mainly focus on the use of internet of things (IoT) and cyber-physical systems (CPS) in industries (Xu et al., 2018), thus promoting the use of user-generated data. Therefore, the researchers and practitioners were able to study and implement the SM to improve firms' productivity and performance. USA alone is responsible for $30 \%$ of the total articles published. China follows USA with nine and United Kingdom with six research papers published on SM-OSCM intersection.

Further, this is followed by Australia, Greece, Hong Kong, Taiwan and Turkey having two papers each (Figure 5). These top eight countries account for $78 \%$ of the total articles published on this emerging topic. While the other countries shown in Figure 5 have one publication each. The reason for the low contribution from other countries could be lack of resources, including availability and access to data. The researchers need both firm-level data and SM data 
available on SM platforms to explore the operational value of SM in OSCM (Cui et al., 2018), which is difficult to obtain.

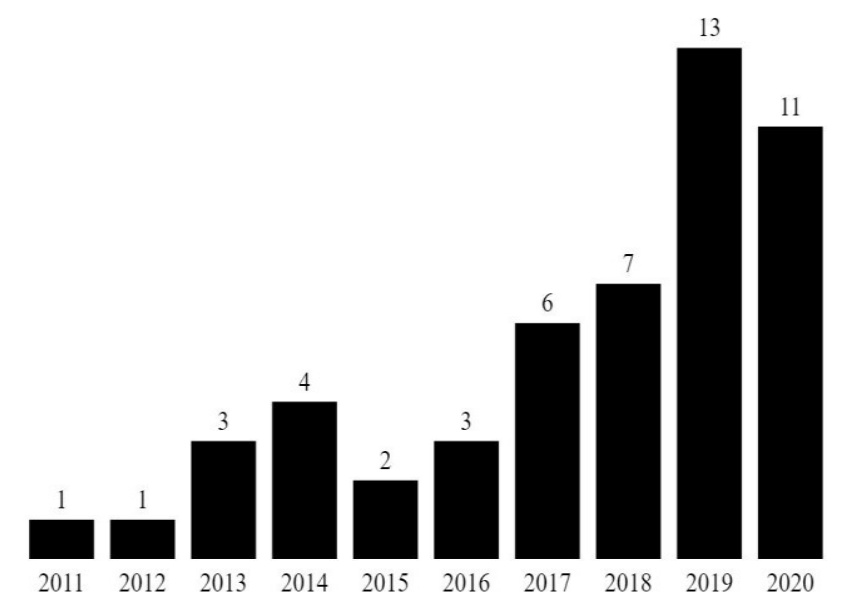

Figure 4 Year-wise distribution of selected studies

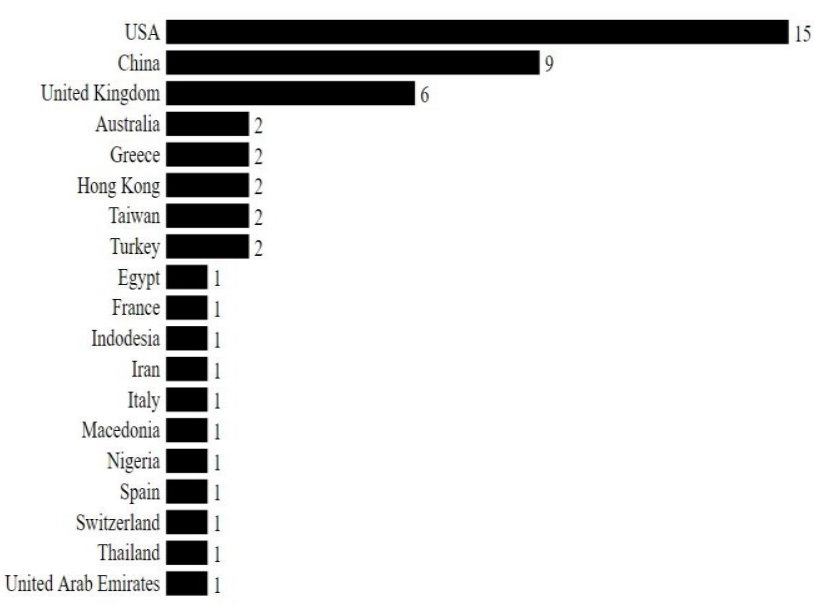

Figure 5 Country-wise distribution of selected studies

\subsection{Papers Published by Journal/Conference}

The data on the number of articles published, until October 2020, by journals/conferences are shown in Table 3. International Journal of Operations and Production Management (9 papers), Production and Operation Management (4 papers), Journal of Operations Management (3 papers), Annals of Operations Research (3 papers) and International Journal of Production Research (3 papers) are the top contributors. These journals are followed by International Journal of Production Economics (2 papers) and Journal of Cleaner Production (2 papers). Other reputed OSCM journals with high impact factor, such as Supply chain management: An international journal, International Journal of Physical Distribution and Logistics Management, International Journal of Productivity and Performance Management and Transportation Research Part E: Logistics and Transportation Review published one article each (Table 3). We find that the number of research papers published in leading OSCM journals is less; this suggests that the topic is still in its infancy. The reason could be the unfamiliarity of the OSCM researchers about the application areas of SM in the OSCM context.
Table 3. Papers published by journals

\begin{tabular}{|c|c|}
\hline Journal/Conference & Papers \\
\hline $\begin{array}{l}\text { International Journal of Operations and Production } \\
\text { Management }\end{array}$ & 9 \\
\hline Production and Operations Management & 4 \\
\hline Journal of Operations Management & 3 \\
\hline Annals of Operations Research & 3 \\
\hline International Journal of Production Research & 3 \\
\hline Journal of Cleaner Production & 2 \\
\hline International Journal of Production Economics & 2 \\
\hline Supply chain management: An international journal & 1 \\
\hline $\begin{array}{l}\text { International Journal of Physical Distribution and Logistics } \\
\text { Management }\end{array}$ & 1 \\
\hline $\begin{array}{l}\text { International Journal of Productivity and Performance } \\
\text { Management }\end{array}$ & 1 \\
\hline International Journal of Supply Chain Management & 1 \\
\hline Journal of Academic and Marketing Science & 1 \\
\hline $\begin{array}{l}\text { Transportation Research Part E: Logistics and } \\
\text { Transportation Review }\end{array}$ & 1 \\
\hline Journal of Hospitality and Tourism insights & 1 \\
\hline Production planning and control & 1 \\
\hline sustainability & 1 \\
\hline Marshall School of Business & 1 \\
\hline $\begin{array}{l}\text { International conference on sustainable design and } \\
\text { manufacturing }\end{array}$ & 1 \\
\hline $\begin{array}{l}\text { The Proceedings of Annual meeting, decision science } \\
\text { institute }\end{array}$ & 1 \\
\hline The service industries Journal & 1 \\
\hline $\begin{array}{l}\text { WIT Transactions on Information and Communication } \\
\text { Technologies }\end{array}$ & 1 \\
\hline 21st American Conference on Information Systems & 1 \\
\hline $6^{\text {th }}$ Int. Conference on Enterprise Information Systems & 1 \\
\hline British Food Journal & 1 \\
\hline Intelligent systems in Accounting, Finance and Management & 1 \\
\hline $\begin{array}{l}\text { International Journal of Communication, Network and } \\
\text { Systems science }\end{array}$ & 1 \\
\hline Amfiteatru Economic Journal & 1 \\
\hline Cornell Hospitality Quarterly & 1 \\
\hline ASBBS Proceedings of the 26th Annual Conference & 1 \\
\hline Decision Support Systems & 1 \\
\hline Foods & 1 \\
\hline Journal of Business and Industrial Marketing & 1 \\
\hline
\end{tabular}

\subsection{Employed Research Methods}

The articles selected for the purpose of review employed different research methods, presented in Figure 6. We found that analytical and survey are the two most popular methods among the researchers, with fifteen and nine papers, respectively. Approximately $47 \%$ of articles considered for review used either analytical or survey method. The use of analytical was found in research articles published after 2014. Under analytical method analysis, techniques such as thematic analysis, sentiment analysis, clustering, and regression analysis are more popular among researchers.

Structural equation modelling was performed in the survey methods to assess the impact of SM on different areas of OSCM. Eight papers used quantitative method, particularly the multi-criteria decision-making technique (MCDM) and optimization modelling. There are seven qualitative studies with all four-exploring application of SM 
on different areas of OSCM including service improvement, relationship building, knowledge sharing and project management. Five articles are conceptual papers. We also found that conceptual papers on SM-OSCM intersection were published on or before 2014. The articles published after 2014 are focused on demonstrating the applications of SM in the OSCM area. Four papers adopted the case study method. These studies aimed at exploring enablers and barriers of SM adoption, supplier selection and assessing factors affecting organizational performance. Finally, the experimental design was used by two studies and mixedmethod by only one study. Since the literature on the topic is less, there is a need for studies with real cases reporting the type of SM platforms used and their use in the OSCM context.

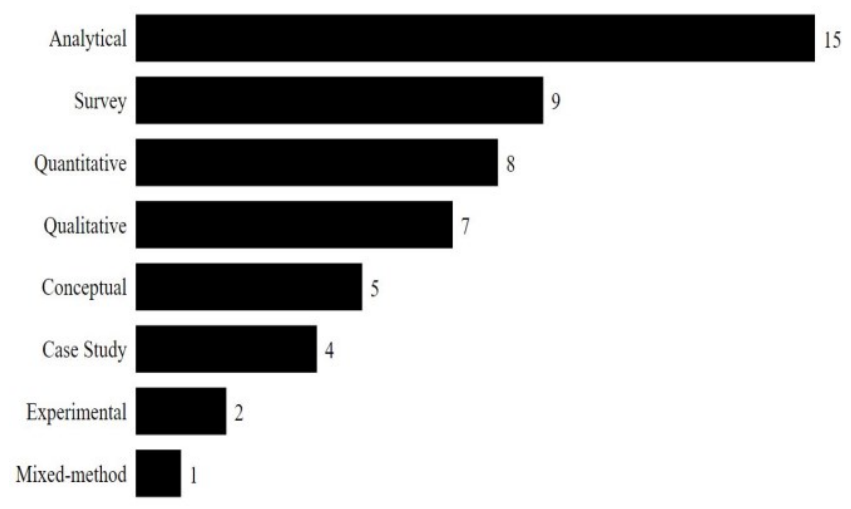

Figure 6 Research methods used by the selected studies

\subsection{SM Application Areas}

From the review of the articles published on SMOSCM intersection, we discovered various areas of application. A few significant applications areas are discussed in this section.

\subsubsection{Integration and Relationship Building}

SM assists organizations in building a connection with both its suppliers and customers (Denktaş-Şakar and Sürücü, 2018; Truong et al., 2020). The use of SM, which earlier mainly dealt in business-to-customer (B2C) settings, has now extended in business-to-business (B2B) settings. Almost $93 \%$ of the B2B marketers use SM platforms for interaction, and as of 2010 , on an average, the fortune 100 companies had $20 \mathrm{SM}$ accounts each to interact with the stakeholders (Rapp et al., 2013). Denktaş-Şakar and Sürücü (2018) in their study highlight that the content type and the type of media posted by a business significantly affects its third-party logistics company as the industrial information shared through SM keeps them updated. Further, the thirdparty logistics companies feel important and valued when firms share celebration on SM platforms that received a positive reaction.

Rapp et al. (2013) find that the use of SM has a positive impact on customer-retailer loyalty, retailer performance and brand performance. As compared to traditional websites, SM platforms foster stakeholder integration through openness and goodwill (Calefato et al., 2014). For example, Facebook fan page offers opportunities to determine the information that causes affective evaluation. Notably, it is easy for participants to assess the benevolence of the potential suppliers, i.e., their clear and optimistic inclination towards the needs and satisfaction of the customers (Calefato et al., 2014). This is majorly because SM establishes interpersonal aspects such as the peer-to-peer, and word of mouth relationships. Similarly, different stakeholder enhances the customers' satisfaction because of their engagement and integration at SM platforms (Wang et al., 2020). Similarly, Tóth et al. (2019) reported that the supplier activities on SM such as sharing of written messages, pictures, audio materials, animation, videos etc. helps in creating a positive word of mouth, reaching-out targeted buyers, and establishing an interface between supplier and buyer.

\subsubsection{Information and knowledge sharing}

OSCM scholars highlight that information and knowledge flow is the foundation of an effective and efficient supply chain (Khan et al., 2019). An organization can build a two-way relationship with its stakeholders through an organized flow of information, resources, and decisions, that can be achieved with SM's integration in OSCM (Sianipar and Yudoko, 2014). The SM with its diverse capabilities allows for integration at the various level, which assist in knowledge and information flow. The SM supports information sharing at three different levels, 1) use of SM across a supply chain for exchanging the information between a particular sender and a receiver enabling the person-to-person information and knowledge sharing. For example, O'leary (2012) highlighted that SM usage boosts individuals' in-role and extra-role knowledge sharing that improve the individual employee's performance. Cui et al. (2019) argued that team SM usage enables the employees to share their knowledge with others to help them in training and improve their job performance. 2) Integration across the various functions of supply chain (e.g., sourcing, inbound and out bond logistics, sales and customer services). Its purpose is not only to create a person-to-person link but also to integrate their departments for knowledge sharing. As per the communication visibility theory team SM usage enhances communication visibility due to open, transparent exchange of information among various departments (Cui et al. 2019). 3) Creating a valued network, i.e., connecting one firm with the other for timely information sharing, and improving supply chain efficiency (Sharma and Khanna, 2020).

Some of the advantages of SM integration in OSCM include the availability of the enormous amount of information, improved visibility of communication, information and knowledge flow in multiple directions and depth of information through the availability of numerous views (O'leary, 2012). Grant (2017) and Irani et al. (2017) also support the idea of the use of SM platforms for information sharing in the insurance industry and during product design, respectively. Despite the advantages of information and knowledge sharing, the potential drawbacks of SM adoption are of significant concern, that has not gained popularity among the researchers. Some disadvantages include employee's distraction from workrelated communication due to too much interaction on SM platform, and chances of leakage of confidential information due to the outflow of the firm's data to external sources (Lam et al., 2016). Similarly, the use of SM after working hours for the work-related task in a large organization leads to emotional fatigue that in turn, aggravates the turnover 
intentions of supply chain professionals. Moreover, it enforces the employees to quit their jobs that disturb the supply chain activities and deplete the performance of the firm (Tang et al., 2019). It becomes necessary to consider the negative side of SM adoption while integrating SM and OSCM.

\subsubsection{Operational efficiency}

Operational efficiency defined as firm's operational performance focused on activities such as profit maximization, cost reduction, waste reduction etc., has long been proved to help firms in gaining competitive advantage and sustaining business (Moyano-Fuentes et al., 2020). Scholars argue that information technology, such as SM, with its diverse capabilities, assists in achieving this operational efficiency, ultimately leading to improved firm performance (Lam et al., 2016). For example, Lam et al. (2016) in their study highlighted that SM platforms enable knowledge sharing, which enhances coordination and helps firms to be more customer-oriented, resulting in improved innovativeness and operational efficiency. Tseng et al. (2019) showed that the integration of attributes such as dynamic capabilities and social capabilities, along with SM utilization promotes competitiveness and improves the firm's performance. Song et al. (2015) reported that the adoption of SM in OSCM operations allows firms to scan customer market, understand customer sentiments and needs, and help in responding to customer requirements efficiently.

Orji et al. (2020) identified factors that foster the adoption of SM in logistics and supply chain. The authors reported that customer satisfaction, sufficient security and privacy, affordability and competitive pressure are significant factors that foster the adoption of SM in logistics. Orji et al. (2020) argued that these factors not only support SM adoption but also assist in achieving supply chain social sustainability. In the context of firm reputation, Guo et al. (2020) reported that the reputation of a firm increases with higher use of SM-based customer services, ultimately leading to improved firm performance. The reason is that in recent years the use of SM by the consumers has increased drastically, and hence the use of SM to report a complaint or provide product feedback. Thus, firms actively using SM platforms can retrieve information related to product/services perceived by the consumers, thus helping to respond to complaints in a better way. Apart from this, Banerjee et al. (2020) argued that the firms could use SM platforms for supplier selection. For this purpose, the firms could make use of intentional signals such as certification, and unintentional signals such as electronic word of mouth (i.e., use of SM platforms for obtaining feedback ratings). The authors highlight that the supplier selection using unintentional signals reduces information asymmetry and improves firms' market performance.

\subsubsection{Forecasting and new product development}

Sales forecasting is a traditional topic in OSCM area, facilitating firms in decision making (Ishichi et al., 2019). The accurate forecast allows firms in improved inventory management, predicting future earnings, and estimating growth (Cui et al., 2018). The research articles on forecasting use operations information, accounting variables, and market data for prediction (Yudhistyra et al., 2020). However, the use of user-generated data for forecasting in research papers is rarely used. One such study by Cui et al. (2018) used social media data to forecast sales. They employed machine learning techniques, specifically seven widely used statistical models were used. Results of the study support the SM's ability to improve sales forecast. However, the quantity of unorganized data available on SM makes it challenging to understand which factors are more critical in prediction.

The idea of adoption of SM for NPD was supported by Chan et al. (2017), Irani et al. (2017), Cheng et al. (2018), and Giannakis et al. (2020). In the context of supplier involvement, Cheng et al. (2018) performed a longitudinal survey of 367 firms from seven manufacturing industries. They reported that SM, along with technological and market knowledge processing capability, enhances supplier involvement in NPD. The corporate discussion forums of organizations enable them to gather stakeholders from different backgrounds to brainstorm and create new ideas (Martini et al., 2014; Zhan et al., 2020). With regards to consumer involvement, Chan et al. (2017) demonstrated the use of SM platform in identifying customer-preferred characteristics of a new product. In particular, the authors retrieved consumer comments from Facebook and performed text analysis to prioritize product characteristics deemed necessary by the consumers. Giannakis et al. (2020) studied the variation in consumer sentiments at different stages of NPD. The data of consumer sentiments expressed on Twitter was collected by the authors to achieve the stated objective. Their results show that consumer sentiments could assist in identifying capabilities and drawbacks of new product/service. Here the idea is to extract relevant information related to product characteristics and customer emotions related to the product; this could assist firms in decision making related to NPD. Based on the review, we found that the number of articles advocating the use of SM for NPD is significantly less; hence more studies with diverse methods are needed to gain a better understanding.

\subsubsection{Emergency services}

Studies on describing the applicability of SM platforms in humanitarian operations have increased in recent years. To start with, Yan and Martinez (2019) reported that in case of disaster management and relief operations, the relief organizations use SM for sharing the information such as evacuation routes, providing updates, and distribution of supplies. Moreover, the individual users can also exchange the information regarding demand of aid, willingness for donation, availability for helping victims during the preparedness, response and recovery of a disaster etc. Similarly, Nilsang et al. (2019) demonstrated the use of realtime SM data to determine ambulance location to minimize response time during emergencies and disaster. The authors developed a maximum covering model for managing emergencies in Bangkok, Thailand, using real-time Twitter data. For example, tweets per unit time related to bizarre incidents e.g., floods, earthquakes, terrorist attacks etc. could be extracted, and their details could be used to find out the right location for ambulance assignment.

Apart from this, Alkhatib et al. (2019) described the utility of SM platforms in providing early warning signs to 
the rescue team in case of an incident. Specifically, Alkhatib et al. (2019) proposed a framework for incidents management in smart cities. They utilized social media feeds using text mining, text classification, and name entity recognition techniques for analysis. The authors argued that in smart cities, the SM platforms that enable public-reported information sharing could assist the decision-makers in improved situational awareness in case of difficult circumstances. The SM platforms could also allow unprecedented access to real-time information of the ongoing incident by general public reporting. Wamba et al. (2019) highlighted that the use of SM in emergency services is still at its nascent stage. Drawing from the case study of Australian emergency services, the authors report several internal and external factors that influence the adoption of $\mathrm{SM}$ in emergency services. The external factors include, use of SM in past emergencies and the SM bandwagon effect. In comparison, the critical internal factors include leader's inclination and support for the use of SM in emergency operations, and the technological development of the SM platforms and state emergency services' site.

\section{The Future of SM in OSCM}

We conducted a SLR of the extant literature to provide a comprehensive overview of SM in OSCM. Findings of our study show that the research papers on the applicability of $\mathrm{SM}$ in OSCM are less and have increased in recent years. We are indicating that the area is still at its nascent stage but evolving rapidly. We believe that the topic has enormous potential, and even small research efforts in this direction could significantly extend the body of knowledge. Based on the critical analysis of the past studies on SM-OSCM intersection, we propose several research avenues which could assist future researchers in advancing in this direction.

\subsection{Research Avenues by Countries}

Results show that majority of the studies have been performed in USA, followed by China, and United Kingdom respectively. Whereas very few studies have been conducted in other countries context. This shows that the potential of $\mathrm{SM}$ in improving OSCM is still under-explored in many countries. Culture varies across countries, and so does the customer needs and the perception that largely depends on culture. For example, people of developed countries put more importance on social-product attributes, whereas that of developing countries put the matter on general product attributes (Bangsa and Schlegelmilch, 2020). Thus, future work could focus on using SM to understand the needs of business/individual customers.

Findings show that most of the studies have been performed in a single country context. For example, Tang et al., (2019) studied the adverse side effects of SM on turnover intentions of supply chain professionals in the context of Chinese manufacture only. Wang et al. (2020) explored the impact of SM analytics on customer satisfaction in the service organization operating in Greece. Similarly, Orji et al. (2020) investigated the factors responsible for the adoption of SM for supply chain social sustainability in the Nigerian freight logistics industry. Thus, the researchers could perform a cross-cultural study to explore cultural differences. These findings will help companies in aligning their products and services as per their cultural needs.

\subsection{Research Avenues Based on Research Methods}

The reviewed studies have adopted various research method to perform the analysis. From Figure 6, it is evident that the analytical method is most popular among the researchers followed by survey method and quantitative techniques, respectively. However, other methods, such as mixed-method approach have not received much attention from the research community (see Figure 6). We argue that, as the data obtained from SM platforms is vast and diverse, its reliability could be questioned as a particular section of the society may not be using SM platform to discuss product/services. Hence the authors could use the mixedmethod approach to strengthen their findings. For example, Guo et al., (2020) investigated the relationship between SM and firm reputation using data from SM platform. Such studies could be further extended by using survey method, on the targeted group, to support the findings. Moreover, expert opinions using Delphi method or multi-criteria decision making (MCDM) methods could be used to see whether there is a difference between what experts opine vs what results were obtained from SM data analysis. Thus, strengthening the reliability and validity of the results.

\subsection{Research Avenues Based on the Integration and Relationship Building}

Integration and relationship building had been a prominent area of research among SM-OSCM scholars. The scholars have investigated diverse levels of integration and relationship building. For instance, Calefato et al. (2014) worked on the relationship between low-risk retail companies and their customers. They reported that trustbuilding through SM platform plays a vital role in strengthening the relationship between the firm and its customers. Tóth et al. (2019) worked on improving the buyer-supplier relation at senior manager level; their results supported the emerging role of SM on improving buyersupplier integration. Despite the growing number of studies, the total number of studies on the topic is still significantly less. We suggest future research to explore integration and relationship building on several levels such as buyer-supplier level, firm-bulk customer level, firm-individual customer level etc. For firm-individual customer level integration and relationship building, the researchers could study the impact of problem resolution through SM platforms, and gathering feedback through SM on customer satisfaction. This could help in improving the relationship with the customer. Moreover, researchers could assess the usefulness of SM platform in understanding customer requirements and designing the product/service as per their needs, thus integrating customer in NPD and service improvement.

At buyer-supplier level, the future work could look into various drivers and barriers that affect SM implementation. Moreover, researchers could also be explored the impact of information and knowledge flow through SM on buyersupplier relation. Finally, at the firm-bulk customer level, future research could examine the effects of SM on firm-bulk customer relation. Identification of other external factors that negatively affect the integration and relationship of firmbulk customer relation and whether SM could reduce these negative impacts could also be explored in future. Such findings would provide an in-depth understanding to the 
decision-makers and researchers about the possible positive implications of SM.

\subsection{Research Avenues Based on the Forecasting and NPD}

Forecasting forms an inevitable part of any business. Accurate forecast assists firms in estimating revenue from sales, making production and operations strategies, smoother staff scheduling, reduction in safety inventory cost, developing market strategies, and reducing delay in product delivery (Fan et al., 2017). Scholars highlight that the SM data, consists of people's emotions, advertisements, product feedback, and word of mouth, could be used to improve the forecasting accuracy (Fan et al., 2017; Cui et al., 2018). However, various challenges, such as difficulty in data extraction, data analysis, and data interpretation, are associated with the SM data. For example, the SM data contains a lot of information in the form of comments, rating, reviews, and emojis posted by customers (Chan et al., 2017). Extraction and analysis of such data due to its vastness and complexity is challenging. Hence, future work could develop new methods and novel algorithms for the mining and analysis of SM data efficiently and effectively.

Moreover, in recent years, several models have been developed in the area of marketing management to understand customer sentiments. Some of these models include the Bass model, Norton model, technology diffusion model, new product sales forecasting model, and contingent diffusion model. The researchers could consider exploring these models in OSCM context. Integration of these sentiment analysis techniques with forecasting techniques should be explored, which could further improve the forecasting accuracy.

Apart from this, researchers could also adopt the survey method to understand various SM related factors that could impact a firm's decision on NPD. For example, Cheng et al. (2018) studied the effect of supplier involvement on NPD performance with SM use as a moderating variable. The NDP performance was considered to be composed of product innovativeness, market performance, and financial performance. Similarly, future investigations could be performed to assess the role of supplier involvement through SM at various stage of NPD. For instance, during the commercialization stage of NPD the use of SM may assist firms in new product launching activities, reducing the hurdles, and designing efficient supply chain network to efficiently respond to customer needs while staying lean in terms of inventory. Such research work could be further expanded by studying the impact of suppliers' cultural variables which is likely to impact supplier attitude and involvement in NPD.

\subsection{Miscellaneous Research Directions}

From an industry survey, it was reported that the firms engaged in retailing, manufacturing, and logistics could make maximum use of traditional data such as geo-location, mapping, traceability, etc., for improving supply chain performance. However, of the total companies surveyed, only $1 \%$ reported using SM data for OSCM (Chae, 2015). Hence, we recommend exploring the factors responsible for the low adoption of SM in OSCM context. The findings highlight that the SM-OSCM integration aimed at improving relationship, providing information, knowledge sharing, improving visibility, harnessing feedback into the supply chain, building trust and enhancing service recovery process has been studied in both $\mathrm{B} 2 \mathrm{~B}$ and $\mathrm{B} 2 \mathrm{C}$ context. However, the SM-OSCM integration will not only transform the relationship in $\mathrm{B} 2 \mathrm{~B}$ and $\mathrm{B} 2 \mathrm{C}$ setting but also in customer-tocustomer (C2C) context. SM provides a platform to disseminate emotions and experience, share and give positive comments to friends and followers (Cui et al., 2018). Hence, future research could model the impact of SM on OSCM, considering endorsement effect. The rate of spread of positive/negative endorsement on various SM platforms could be compared to gain a better understanding of their efficacy.

Infrastructure and competence are vital for making use of SM data. This is because the SM data is a form of big data which requires sophisticated machines for data mining and analysis. Moreover, a skilled workforce is needed to perform analysis and draw relevant results from the highly unstructured SM data. Based on the above arguments, we opine researchers to study firms' infrastructure and competence to understand whether the firms are ready for SM adoption in their supply chains. This would also highlight the infrastructure and competence related challenges faced by the firms. Another valuable contribution could be the investigation of a diverse set of challenges that an organization faces before, during, and after the adoption of SM in OSCM. Findings of such research could be of interest to decision-makers, as they would get a fair understanding of the challenges that they need to face at different levels for successful adoption of SM from OSCM. Next, the SM platforms facilitate the interaction with, and among the stakeholders, which can impact the behaviour. Thus, future work can study the behavioural dynamics of stakeholders. Finally, notwithstanding the advantages, the negative effects of SM-OSCM integration cannot be ignored. Some of the negative impacts include the outflow of confidential information, the distraction of employees from work due to excessive use of SM platform. Hence, we encourage the researchers to explore various other negative impacts of SM adoption. This would help to keep practitioners informed, well in advance, about the harmful effect SM adoption could bring to the supply chain.

\section{PRACTICAL AND THEORETICAL IMPLICATIONS}

The study outlines managerial/practical implications for decision-makers, policymakers, and consultants interested in gaining a deeper understanding of SM-OSCM integration. The SM related disruption in the OSCM is its contribution to information and knowledge dissemination. The SM platforms allow improved visibility, the multidirectional flow of information, and permits inputs from stakeholders. This helps organizations in maintaining a good relationship with its stakeholders. The engagement of customers and suppliers in NPD is another area of OSCM in which firms are using SM. One such example is Starbucks that had launched its SM platform named "My Starbucks idea" to gather customer inputs for developing new drinks (Lam et al., 2016). The modern consumers are more aware, and they compare the price and quality of product/service 
before making a decision. Therefore, retaining customers has been identified as a key challenge (Ampountolas et al., 2019). Hence, industries such as hospitality, tourism, airlines etc. use SM for promotions and dynamic pricing. The SM adoption can be increased by embedding personalization features to engage with users or community by communication the sense of belongingness. Moreover, the focus should be on content and relationship aspects while designing the platform (Wamba et al., 2017).

From the theoretical perspective, the study provides necessary insights to the scholars interested in advancing research in SM-OSCM integration. As highlighted earlier, the study on SM-OSCM integration is in the initial stage not only in developing countries but also in developed countries. The first study on SM application in OSCM was published in 2011, and since then there has been an increase in the number of studies on this topic. Further, we expect that the number of publications on the subject will grow shortly. As underlined, the importance of SM for enhancing OSCM suggests that SM could be exploited and explored for obtaining OSCM advantage.

\section{CONCLUSION}

This study reviewed the current literature on SMOSCM intersection. SLR approach was adopted for discovering the application of SM in the OSCM context and describing its advantages to the OSCM field. The results revealed that although the topic is still in the nascent stage, the use of data available on SM platforms can substantially benefit firms. Although the study highlights some of the exciting insights into the SM-OSCM literature, the study has some limitations. A limited number of keywords are used while searching for articles. All the authors combinedly decided these keywords. Use of other keywords may yield different results, but their relevance to the topic is questionable. Another limitation of the study is that only those papers are considered for review, which the authors believe have worked in SM-OSCM intersection. However, the list is comprehensive as the majority of the high-ranked journals of the field are covered.

\section{REFERENCES}

Abidi, H., de Leeuw, S. and Klumpp, M., (2014). Humanitarian supply chain performance management: a systematic literature review. Supply Chain Management: An International Journal 19(5/6), pp. 592-608.

Abrizah, A., Zainab, A.N., Kiran, K. and Raj, R.G., (2013). LIS journals scientific impact and subject categorization: a comparison between Web of Science and Scopus. Scientometrics 94(2), pp. 721-740.

Alkhatib, M., El Barachi, M., \& Shaalan, K. (2019). An Arabic social media-based framework for incidents and events monitoring in smart cities. Journal of Cleaner Production 220, pp. 771-785.

Ampountolas, A., Shaw, G. and James, S., (2019). The role of social media as a distribution channel for promoting pricing strategies. Journal of Hospitality and Tourism Insights 2(1), pp. 75-91.

Banerjee, A., Ries, J. M., \& Wiertz, C. (2020). The impact of social media signals on supplier selection: insights from two experiments. International Journal of Operations \& Production Management 40(5), pp. 531-552.

Bangsa, A. B., \& Schlegelmilch, B. B. (2020). Linking sustainable product attributes and consumer decision-making: Insights from a systematic review. Journal of Cleaner Production 245, 118902.

Bastas, A. and Liyanage, K., (2018). Sustainable supply chain quality management: A systematic review. Journal of Cleaner Production 181, pp.726-744.

Behera, R.K., Bala, P.K. and Dhir, A., (2019). The emerging role of cognitive computing in healthcare: A systematic literature review. International Journal of Medical Informatics 129, pp.154-166.

Bhimani, H., Mention, A.L. and Barlatier, P.J., (2019). Social media and innovation: a systematic literature review and future research directions. Technological Forecasting and Social Change 144, pp.251-269.

Briner, R.B. and Denyer, D., (2012). Systematic review and evidence synthesis as a practice and scholarship tool. The Oxford handbook of evidence-based management: Companies, classrooms and research, pp.112-129.

Calefato, F., Lanubile, F. and Novielli, N., (2014), April. Investigating the Effect of Social Media on Trust Building in Customer-supplier Relationships. In ICEIS (2), pp. 635-642.

Centobelli, P., Cerchione, R. and Esposito, E., (2018) Environmental sustainability and energy-efficient supply chain management: A review of research trends and proposed guidelines. Energies 11(2), p. 275.

Carlo Bertot, J., Jaeger, P.T. and Grimes, J.M., (2012). Promoting transparency and accountability through ICTs, social media, and collaborative e-government. Transforming Government: People, Process and Policy 6(1), pp.78-91.

Cerchione, R. and Esposito, E., (2016). A systematic review of supply chain knowledge management research: State of the art and research opportunities. International Journal of Production Economics 182, pp.276-292.

Chae, B.K., (2015). Insights from hashtag\# supply chain and Twitter Analytics: Considering Twitter and Twitter data for supply chain practice and research. International Journal of Production Economics 165, pp. 247-259.

Chan, H.K., Lacka, E., Yee, R.W. and Lim, M.K., (2017). The role of social media data in operations and production management. International Journal of Production Research 55(17), pp. 5027-5036.

Chen, L., Zhao, X., Tang, O., Price, L., Zhang, S. and Zhu, W., (2017). Supply chain collaboration for sustainability: A literature review and future research agenda. International Journal of Production Economics 194, pp. 73-87.

Cheng, C.C. and Krumwiede, D., (2018). Enhancing the performance of supplier involvement in new product development: the enabling roles of social media and firm capabilities. Supply Chain Management: An International Journal 23(3), pp. 171-187.

Choi, T. M., Guo, S., \& Luo, S. (2020). When blockchain meets social-media: Will the result benefit social media analytics for supply chain operations management?. Transportation Research Part E: Logistics and Transportation Review 135, 101860.

Constantinides, E. and Fountain, S.J., (2008). Web 2.0: Conceptual foundations and marketing issues. Journal of Direct, Data and Digital Marketing Practice 9(3), pp. 231-244.

Cochrane Library, (2018). "Cochrane database of systematic reviews", available at: www.cochranelibrary.com/cdsr/aboutcdsr (access 28 November, 2019).

Cooke, M. and Buckley, N., (2008). Web 2.0, social networks and the future of market research. International Journal of Market Research 50(2), pp. 267-292.

Cui, R., Gallino, S., Moreno, A. and Zhang, D.J., (2018). The operational value of social media information. Production and Operations Management 27(10), pp. 1749-1769.

Cui, X., Huo, B., Lei, Y., \& Zhou, Q. (2019). The influence of team social media usage on individual knowledge sharing and job performance from a cross-level perspective. International 
Journal of Operations \& Production Management 40(5), pp. 553-573.

Davies, H.T. and Crombie, I.K., (1998). Getting to grips with systematic reviews and meta-analyses. Hospital medicine (London, England: 1998) 59(12), pp.955-958.

Denktaş-Şakar, G. and Sürücü, E., (2018). Stakeholder engagement via social media: an analysis of third-party logistics companies. The Service Industries Journal 40(11-12), pp.866-889.

Denyer, D. and Tranfield, D., (2009). Producing a systematic review. The Sage Handbook of Organizational Research Methods, pp.671-689.

Dubey, R. and Ali, S.S., (2015). Exploring antecedents of extended supply chain performance measures: an insight from Indian green manufacturing practices. Benchmarking: An International Journal, 22(5), pp.752-772.

Dubey, R., Gunasekaran, A. and Papadopoulos, T., (2017). Green supply chain management: theoretical framework and further research directions. Benchmarking: An International Journal, 24(1), pp.184-218.

Eftekhar, M., Li, H., Van Wassenhove, L.N. and Webster, S., (2017). The role of media exposure on coordination in the humanitarian setting. Production and Operations Management, 26(5), pp.802-816.

Elghannam, A., Escribano, M. and Mesias, F., (2017). Can social networks contribute to the development of short supply chains in the Spanish agri-food sector? New Medit, 16(1), pp.36-42.

Elghannam, A., Arroyo, J., Eldesouky, A. and Mesias, F.J., (2018). A cross-cultural consumers' perspective on social mediabased short food supply chains. British Food Journal, 120(10), pp.2210-2221.

Elghannam, A., Mesias, F. J., Escribano, M., Fouad, L., Horrillo, A., \& Escribano, A. J. (2020). Consumers' Perspectives on Alternative Short Food Supply Chains Based on Social Media: A Focus Group Study in Spain. Foods, 9(1), p 22.

Fan, Y. and Niu, R.H., (2016). To tweet or not to tweet? Exploring the effectiveness of service recovery strategies using social media. International Journal of Operations \& Production Management, 36(9), pp.1014-1036.

Fan, Z. P., Che, Y. J., \& Chen, Z. Y. (2017). Product sales forecasting using online reviews and historical sales data: A method combining the Bass model and sentiment analysis. Journal of Business Research, 74, pp. 90-100.

Fisher, R., McPhail, R., You, E. and Ash, M., (2014). Using social media to recruit global supply chain managers. International Journal of Physical Distribution \& Logistics Management, 44(8/9), pp.635-645.

Friday, D., Ryan, S., Sridharan, R. and Collins, D., (2018). Collaborative risk management: a systematic literature review. International Journal of Physical Distribution \& Logistics Management, 48(3), pp.231-253.

Gebremikael, F., Szmerekovsky, J. and Gaypong, S., (2019). Leveraging social media platforms to acquire supply chain intelligence with a view to improving supply chain performance using the AHP. ASBBS Proceedings, 26, pp.234-249.

Giannakis, M., Dubey, R., Yan, S., Spanaki, K., \& Papadopoulos, T. (2020). Social media and sensemaking patterns in new product development: demystifying the customer sentiment. Annals of Operations Research, pp. $1-31$.

Gough, D., Oliver, S. and Thomas, J., (2012). Introducing Systematic Reviews, Sage Publications, London.

Govindan, K. and Hasanagic, M., (2018). A systematic review on drivers, barriers, and practices towards circular economy: a supply chain perspective. International Journal of Production Research, 56(1-2), pp.278-311.

Grant, S.B., (2017), April. Barriers and Enablers to Supply Chain Knowledge Sharing and Learning Using Social Media.
In International Conference on Sustainable Design and Manufacturing (pp. 375-385). Springer, Cham.

Guo, Y., Fan, D., \& Zhang, X. (2020). Social media-based customer service and firm reputation. International Journal of Operations \& Production Management. 40(5), pp.575-601.

Gupta, R. and Brooks, H., (2013). Using Social Media for Global Security. John Wiley \& Sons.

Huddiniah, E., \& ER, M. (2019). Product variety, supply chain complexity and the needs for information technology: A framework based on literature review. Operations and Supply Chain Management: An International Journal, 12(4), pp.245-255.

Idri, A., azzahra Amazal, F. and Abran, A., (2015). Analogy-based software development effort estimation: A systematic mapping and review. Information and Software Technology, 58, pp.206-230.

Irani, Z., Sharif, A.M., Papadopoulos, T. and Love, P.E., (2017). Social media and Web 2.0 for knowledge sharing in product design. Production Planning \& Control, 28(13), pp.10471065.

Ishichi, K., Ohmori, S., Ueda, M., \& Yoshimoto, K. (2019). Shelfspace allocation model with demand learning. Operations and Supply Chain Management: An International Journal, 12(1), 24-40.

Jabeur, N., Nait-Sidi-Moh, A. and Zeadally, S., (2018). Crowd social media computing: Applying crowd computing techniques to social media. Applied Soft Computing, 66, pp.495-505.

Jeble, S., Kumari, S., \& Patil, Y. (2017). Role of big data in decision making. Operations and Supply Chain Management: An International Journal, 11(1), pp.36-44.

Jiang, C., Liu, Y., Ding, Y., Liang, K., \& Duan, R. (2017). Capturing helpful reviews from social media for product quality improvement: a multi-class classification approach. International Journal of Production Research, 55(12), 3528-3541.

Kamble, S.S., Gunasekaran, A. and Gawankar, S.A., (2020). Achieving Sustainable Performance in a Data-driven Agriculture Supply Chain: A Review for Research and Applications. International Journal of Production Economics, 219, pp.179-194.

Kanagarajoo, M.V., Fulford, R. and Standing, C., (2019). The contribution of social media to project management. International Journal of Productivity and Performance Management, 69(4), pp.834-872.

Kaplan, A.M. and Haenlein, M., (2010). Users of the world, unite! The challenges and opportunities of Social Media. Business Horizons, 53(1), pp.59-68.

Kapoor, K.K., Tamilmani, K., Rana, N.P., Patil, P., Dwivedi, Y.K. and Nerur, S., (2018). Advances in social media research: past, present and future. Information Systems Frontiers, 20(3), pp.531-558.

Kietzmann, J.H., Hermkens, K., McCarthy, I.P. and Silvestre, B.S., (2011). Social media? Get serious! Understanding the functional building blocks of social media. Business Horizons, 54(3), pp.241-251.

Khan, I., Rutherford, B., \& Williams, A. (2019). Information Technology Outsourcing: Influence of Supplier Firm Size and Reputation on Buyers' A Priori Perceptions of Opportunism and Uncertainty. Operations and Supply Chain Management: An International Journal, 12(4), 186-197.

Lam, H.K., Yeung, A.C. and Cheng, T.E., (2016). The impact of firms' social media initiatives on operational efficiency and innovativeness. Journal of Operations Management, 47(1), pp.28-43.

Leonardi, P.M., Huysman, M. and Steinfield, C., (2013). Enterprise social media: Definition, history, and prospects for the study of social technologies in organizations. Journal of ComputerMediated Communication, 19(1), pp.1-19. 
Lin, H., Fan, W. and Chau, P.Y., (2014). Determinants of users' continuance of social networking sites: A self-regulation perspective. Information \& Management, 51(5), pp.595-603.

Lin, K.P., Hung, K.C., Lin, Y.T. and Hsieh, Y.H., (2018). Green supplier's performance evaluation in Belt and Road using fuzzy weighted average with social media information. Sustainability, 10(1), p.5.

Liu, Y., Jiang, C., \& Zhao, H. (2019). Assessing product competitive advantages from the perspective of customers by mining user-generated content on social media. Decision Support Systems, 123, 113079.

Markova, S. and Petkovska-Mirčevska, T., (2013). Social media and supply chain. Amfiteatru Economic Journal, 15(33), pp.89-102.

Martini, A., Massa, S. and Testa, S., (2014). Customer co-creation projects and social media: The case of Barilla of Italy. Business Horizons, 57(3), pp.425-434.

McAfee, A., (2009). Enterprise 2.0: New collaborative tools for your organization's toughest challenges. Harvard Business Press.

Mohamad, M.R.A., Ali, M., Abdullah, A.S. and El Fiky, A.S., (2018). The usage of social media and e-reputation system in global supply chain: comparative cases from diamond \& automotive industries. International Journal of Communications, Network and System Sciences, 11(5), pp.69-103.

Mongeon, P. and Paul-Hus, A., (2016). The journal coverage of Web of Science and Scopus: a comparative analysis. Scientometrics, 106(1), pp.213-228.

Moreno-Camacho, C.A., Montoya-Torres, J.R., Jaegler, A. and Gondran, N., (2019). Sustainability Metrics for Real Case Applications of the Supply Chain Network Design Problem: A Systematic Literature Review. Journal of Cleaner Production, 213, pp.600-618.

Moyano-Fuentes, J., Maqueira-Marín, J. M., Martínez-Jurado, P. J., \& Sacristán-Díaz, M. (2020). Extending lean management along the supply chain: impact on efficiency. Journal of Manufacturing Technology Management.

Nasrollahi, M., (2018). The impact of firm's social media applications on green supply chain management. International Journal of Supply Chain Management, 7(1), pp.16-24.

Nilsang, S., Yuangyai, C., Cheng, C. Y., \& Janjarassuk, U. (2019). Locating an ambulance base by using social media: a case study in Bangkok. Annals of Operations Research, 283(1), 497-516.

Nguyen, B., Yu, X., Melewar, T.C. and Chen, J., (2015). Brand innovation and social media: Knowledge acquisition from social media, market orientation, and the moderating role of social media strategic capability. Industrial Marketing Management, 51, pp.11-25.

O'leary, D.E., (2011). The use of social media in the supply chain: Survey and extensions. Intelligent Systems in Accounting, Finance and Management, 18(2-3), pp.121-144.

O'Leary, D.E., (2012). Developing trust and relationships in the supply chain using social media. Marshall School of Business Working Paper.

Orji, I. J., Kusi-Sarpong, S., \& Gupta, H. (2020). The critical success factors of using social media for supply chain social sustainability in the freight logistics industry. International Journal of Production Research, 58(5), 1522-1539.

Ouhbi, S., Idri, A., Fernández-Alemán, J.L. and Toval, A., (2015). Requirements engineering education: a systematic mapping study. Requirements Engineering, 20(2), pp.119-138.

Pereira, C.R., Christopher, M. and Lago Da Silva, A., (2014). Achieving supply chain resilience: the role of procurement. Supply Chain Management: an International Journal, 19(5/6), pp.626-642.
Petticrew, M. and Roberts, H., (2006). How to appraise the studies: an introduction to assessing study quality. Systematic reviews in the social sciences: A practical guide, pp.125-163.

Queiroz, M.M., Telles, R. and Bonilla, S.H., (2019). Blockchain and supply chain management integration: A systematic review of the literature. Supply Chain Management: An International Journal, 25(2), pp.241-254.

Ramanathan, U., Subramanian, N. and Parrott, G., (2017). Role of social media in retail network operations and marketing to enhance customer satisfaction. International Journal of Operations \& Production Management, 37(1), pp.105-123.

Rathore, A.K., Ilavarasan, P.V. and Dwivedi, Y.K., (2016). Social media content and product co-creation: an emerging paradigm. Journal of Enterprise Information Management, 29(1), pp.7-18.

Rathore, A.K., Kar, A.K. and Ilavarasan, P.V., (2017). Social media analytics: Literature review and directions for future research. Decision Analysis, 14(4), pp.229-249.

Rapp, A., Beitelspacher, L.S., Grewal, D. and Hughes, D.E., (2013). Understanding social media effects across seller, retailer, and consumer interactions. Journal of the Academy of Marketing Science, 41(5), pp.547-566.

Salo, J., (2017). Social media research in the industrial marketing field: Review of literature and future research directions. Industrial Marketing Management, 66, pp.115129.

Serbetcioglu, C., \& Göçer, A. (2020). Examining social media branding profiles of logistics service providers. Journal of Business \& Industrial Marketing.

Sharma, A., \& Khanna, P. (2020). Relevance of Adopting Emerging Technologies in Outbound Supply Chain: New Paradigm for Cement Industry. Operations and Supply Chain Management: An International Journal, 13(2), 210-221.

Sianipar, C.P.M. and Yudoko, G., (2014). Social media: toward an integrated human collaboration in supply-chain management. WIT Transactions on Information and Communication Technologies, 53(1), pp.249-266.

Sigala, M., (2014). Customer involvement in sustainable supply chain management: A research framework and implications in tourism. Cornell Hospitality Quarterly, 55(1), pp.76-88.

Schmidt, C. G., Wuttke, D. A., Ball, G. P., \& Heese, H. S. (2020). Does social media elevate supply chain importance? An empirical examination of supply chain glitches, Twitter reactions, and stock market returns. Journal of Operations Management. 66(6), pp.646-669.

Song, J., Shin, S., Jia, L., Cegielski, C. and Rainer Jr, R.K., (2015, August). The Effect of Social Media on Supply Chain Sensing Capability: An Environmental Scanning Perspective. In Twenty-first Americas Conference on Information Systems, Puerto Rico.

Swain, A. and Cao, Q., (2013, November). Exploring the impact of social media on supply chain performance: A sentiment analysis. In The proceedings of 44th Annual Meeting, Decision Sciences Institute, pp. 16-19.

Tang, G., Ren, S., Chadee, D., \& Yuan, S. (2019). The dark side of social media connectivity. International Journal of Operations \& Production Management. 40(5), pp.603-623.

Thomé, A.M.T., Scavarda, L.F. and Scavarda, A.J., (2016). Conducting systematic literature review in operations management. Production Planning \& Control, 27(5), pp.408420.

Tóth, Z., Liu, M., Luo, J., \& Braziotis, C. (2019). The role of social media in managing supplier attractiveness. International Journal of Operations \& Production Management. 40(5), pp.625-646.

Tranfield, D., Denyer, D. and Smart, P., (2003). Towards a methodology for developing evidence-informed management knowledge by means of systematic review. British Journal of Management, 14(3), pp.207-222. 
Truong, N., Dang-Pham, D., McClelland, R., \& Nkhoma, M. (2020). Exploring the Impact of Innovativeness of Hospitality Service Operation on Customer Satisfaction. Operations and Supply Chain Management: An International Journal, 13(3), pp.307-319.

Tseng, M.L., Lim, M.K., Wu, K.J. and Peng, W.W., (2019). Improving sustainable supply chain capabilities using social media in a decision-making model. Journal of Cleaner Production, 227, https://doi.org/10.1016/j.jclepro.2019.04.202

Wamba, S. F., Edwards, A. and Akter, S., (2019). Social media adoption and use for improved emergency services operations: the case of the NSW SES. Annals of Operations Research, 283(1-2), pp.225-245.

Wang, Y., Zhang, M., Tse, Y. K., \& Chan, H. K. (2020). Unpacking the impact of social media analytics on customer satisfaction: Do external stakeholder characteristics matter? International Journal of Operations and Production Management. 40(5), pp.647-669.

Xu, L.D., Xu, E.L. and Li, L., (2018). Industry 4.0: state of the art and future trends. International Journal of Production Research, 56(8), pp. 2941-2962.
Yan, L., \& Pedraza-Martinez, A. J. (2019). Social media for disaster management: Operational value of the social conversation. Production and Operations Management, 28(10), 2514-2532.

Yoo, E., Rand, W., Eftekhar, M. and Rabinovich, E., (2016). Evaluating information diffusion speed and its determinants in social media networks during humanitarian crises. Journal of Operations Management, 45(1), pp.123-133.

Yoo, E., Rabinovich, E., \& Gu, B. (2020). The growth of follower networks on social media platforms for humanitarian operations. Production and Operations Management.

Yudhistyra, W., Risal, E., Raungratanaamporn, I. S., \& Ratanavaraha, V. (2020). Exploring Big Data Research: A Review of Published Articles from 2010 to 2018 Related to Logistics and Supply Chains. Operations and Supply Chain Management: An International Journal, 13(2), 134-149.

Zhan, Y., Tan, K. H., Chung, L., Chen, L., \& Xing, X. (2020). Leveraging social media in new product development: organisational learning processes, mechanisms and evidence from China. International Journal of Operations \& Production Management.40(5), pp.671-695.

Zavala, A., \& Ramirez-Marquez, J. E. (2019). Visual analytics for identifying product disruptions and effects via social media. International Journal of Production Economics, 208, 544-559. 
Devi \& Ganguly: Social Media in Operations and Supply Chain Management: A Systematic Literature Review to Explore the Future Operations and Supply Chain Management 14(2) pp. $232-248$ (C) 2021

APPENDIX

Table A1. Selected studies with journal h-index and citation

\begin{tabular}{|c|c|c|c|c|}
\hline No. & Study & $\begin{array}{l}\text { Journal \& } \\
\text { proceedings }\end{array}$ & $\begin{array}{l}\mathrm{H} \\
\text { index }\end{array}$ & $\begin{array}{l}\text { Citation } \\
\text { no. }\end{array}$ \\
\hline 1 & O'Leary (2011) & $\begin{array}{l}\text { Intelligent systems } \\
\text { in Accounting, } \\
\text { Finance and } \\
\text { management }\end{array}$ & - & 75 \\
\hline 2 & O'Leary (2012) & $\begin{array}{l}\text { Marshall School of } \\
\text { Business }\end{array}$ & - & 10 \\
\hline 3 & $\begin{array}{l}\text { Markova et al. } \\
(2013)\end{array}$ & $\begin{array}{l}\text { Amfiteatru } \\
\text { Economic Journal }\end{array}$ & 14 & 17 \\
\hline 4 & $\begin{array}{l}\text { Swain and Cao } \\
\text { (2013) }\end{array}$ & $\begin{array}{l}\text { The Proceedings of } \\
\text { Annual meeting, } \\
\text { decision science } \\
\text { institute }\end{array}$ & - & 4 \\
\hline 5 & $\begin{array}{lll}\text { Rapp } & \text { et al. } \\
(2013) & & \end{array}$ & $\begin{array}{l}\text { Journal of the } \\
\text { Academy and } \\
\text { marketing science }\end{array}$ & 49 & 353 \\
\hline 6 & $\begin{array}{l}\text { Calefato et al. } \\
(2014)\end{array}$ & $\begin{array}{l}6^{\text {th }} \text { International } \\
\text { Conference on } \\
\text { Enterprise } \\
\text { Information } \\
\text { Systems (ICEIS) }\end{array}$ & 14 & 5 \\
\hline 7 & $\begin{array}{l}\text { Fisher et al. } \\
(2014)\end{array}$ & $\begin{array}{l}\text { International } \\
\text { Journal of physical } \\
\text { distribution and } \\
\text { logistics } \\
\text { management }\end{array}$ & 38 & 18 \\
\hline 8 & Sigala (2014) & $\begin{array}{l}\text { Cornell Hospitality } \\
\text { Quarterly }\end{array}$ & 31 & 66 \\
\hline 9 & $\begin{array}{l}\text { Sianipar and } \\
\text { Yudoko (2014) }\end{array}$ & $\begin{array}{l}\text { WIT Transactions } \\
\text { on Information and } \\
\text { Communication } \\
\text { Technologies }\end{array}$ & - & 5 \\
\hline 10 & Chae (2015) & $\begin{array}{l}\text { International } \\
\text { journal of } \\
\text { production } \\
\text { economics }\end{array}$ & 89 & 204 \\
\hline 11 & $\begin{array}{l}\text { Song et al. } \\
(2015)\end{array}$ & $\begin{array}{l}\text { Twenty-first } \\
\text { Americas } \\
\text { conference on } \\
\text { information } \\
\text { systems }\end{array}$ & - & 1 \\
\hline 12 & $\begin{array}{l}\text { Lam et al. } \\
(2016)\end{array}$ & $\begin{array}{l}\text { Journal of } \\
\text { operations } \\
\text { management }\end{array}$ & 51 & 38 \\
\hline 13 & $\begin{array}{l}\text { Yoo et al. } \\
(2016)\end{array}$ & $\begin{array}{l}\text { Journal of } \\
\text { operations } \\
\text { management }\end{array}$ & 51 & 52 \\
\hline 14 & $\begin{array}{l}\text { Fan and Nui } \\
(2016)\end{array}$ & $\begin{array}{l}\text { International } \\
\text { journal of } \\
\text { operations and } \\
\text { production } \\
\text { management }\end{array}$ & 48 & 11 \\
\hline 15 & $\begin{array}{lll}\text { Irani } & \text { et } & \text { al. } \\
(2017) & & \end{array}$ & $\begin{array}{l}\text { Production, } \\
\text { planning and } \\
\text { control }\end{array}$ & - & 12 \\
\hline 16 & $\begin{array}{l}\text { Chan et al. } \\
(2017)\end{array}$ & $\begin{array}{l}\text { International } \\
\text { Journal of } \\
\text { production } \\
\text { research }\end{array}$ & 63 & 15 \\
\hline 17 & $\begin{array}{l}\text { Eftekhar et al. } \\
(2017)\end{array}$ & $\begin{array}{l}\text { Production and } \\
\text { operations } \\
\text { management }\end{array}$ & 48 & 16 \\
\hline 18 & Grant (2017) & $\begin{array}{l}\text { International } \\
\text { conference on }\end{array}$ & - & 0 \\
\hline
\end{tabular}

\begin{tabular}{|c|c|c|c|c|}
\hline No. & Study & $\begin{array}{l}\text { Journal \& } \\
\text { proceedings }\end{array}$ & $\begin{array}{l}\mathrm{H} \\
\text { index }\end{array}$ & $\begin{array}{l}\text { Citation } \\
\text { no. }\end{array}$ \\
\hline & & $\begin{array}{l}\text { sustainable design } \\
\text { and manufacturing }\end{array}$ & & \\
\hline 19 & $\begin{array}{lll}\text { Jiang } & \text { et al. } \\
(2017) & & \end{array}$ & $\begin{array}{l}\text { International } \\
\text { Journal of } \\
\text { production } \\
\text { research }\end{array}$ & 77 & 10 \\
\hline 20 & $\begin{array}{l}\text { Ramanathan et } \\
\text { al. (2017) }\end{array}$ & $\begin{array}{l}\text { International } \\
\text { journal of } \\
\text { operations and } \\
\text { production } \\
\text { management } \\
\end{array}$ & 48 & 57 \\
\hline 21 & Cui et al. (2018) & $\begin{array}{l}\text { Production and } \\
\text { operations } \\
\text { management }\end{array}$ & 48 & 49 \\
\hline 22 & $\begin{array}{lll}\text { Cheng } & \text { et al. } \\
(2018) & & \end{array}$ & $\begin{array}{l}\text { Supply chain } \\
\text { management: An } \\
\text { International } \\
\text { Journal }\end{array}$ & 46 & 3 \\
\hline 23 & $\begin{array}{l}\text { Elghannam et } \\
\text { al. (2018) }\end{array}$ & British food journal & 37 & 0 \\
\hline 24 & Lin et al. (2018) & Sustainability & 61 & 5 \\
\hline 25 & $\begin{array}{l}\text { Mohammad et } \\
\text { al. (2018) }\end{array}$ & $\begin{array}{l}\text { International } \\
\text { journal of } \\
\text { communication, } \\
\text { network and } \\
\text { system science }\end{array}$ & 14 & 0 \\
\hline 26 & $\begin{array}{l}\text { Nasrollahi } \\
\text { (2018) }\end{array}$ & $\begin{array}{l}\text { International } \\
\text { journal of supply } \\
\text { chain management }\end{array}$ & - & 2 \\
\hline 27 & $\begin{array}{l}\text { Denktaş-Şakar } \\
\text { and Sürücü } \\
(2018)\end{array}$ & $\begin{array}{l}\text { The Service } \\
\text { industries journal }\end{array}$ & 25 & 0 \\
\hline 28 & $\begin{array}{l}\text { Yan and } \\
\text { Martinez (2019) }\end{array}$ & $\begin{array}{l}\text { Production and } \\
\text { operations } \\
\text { management }\end{array}$ & 48 & 0 \\
\hline 29 & $\begin{array}{l}\text { Ampountolas et } \\
\text { al. (2019) }\end{array}$ & $\begin{array}{l}\text { Journal of } \\
\text { Hospitality and } \\
\text { Tourism insights }\end{array}$ & 0 & 0 \\
\hline 30 & $\begin{array}{l}\text { Kanagarajoo et } \\
\text { al. (2019) }\end{array}$ & $\begin{array}{l}\text { International } \\
\text { journal of } \\
\text { productivity and } \\
\text { performance } \\
\text { management }\end{array}$ & 34 & 0 \\
\hline 31 & $\begin{array}{l}\text { Fesseha et al. } \\
\text { (2019) }\end{array}$ & $\begin{array}{l}\text { ASBBS } \\
\text { Proceedings of the } \\
\text { 26th Annual } \\
\text { Conference }\end{array}$ & 9 & 0 \\
\hline 32 & $\begin{array}{l}\text { Wamba et al. } \\
(2019)\end{array}$ & $\begin{array}{l}\text { Annals of } \\
\text { operations } \\
\text { research }\end{array}$ & 46 & 4 \\
\hline 33 & $\begin{array}{l}\text { T Seng et al. } \\
(2019)\end{array}$ & $\begin{array}{l}\text { Journal of Cleaner } \\
\text { production }\end{array}$ & 132 & 0 \\
\hline 34 & $\begin{array}{l}\text { Alkhatib et al. } \\
(2019)\end{array}$ & $\begin{array}{l}\text { Journal of Cleaner } \\
\text { production }\end{array}$ & 154 & 10 \\
\hline 35 & Liu et al. (2019) & $\begin{array}{l}\text { Decision support } \\
\text { systems }\end{array}$ & 60 & 11 \\
\hline 36 & $\begin{array}{l}\text { Nilsang et al. } \\
(2019)\end{array}$ & $\begin{array}{l}\text { Annals of } \\
\text { operations } \\
\text { research }\end{array}$ & 50 & 7 \\
\hline 37 & $\begin{array}{l}\text { Tang et } \\
(2019)\end{array}$ & $\begin{array}{l}\text { International } \\
\text { journal of } \\
\text { operations and } \\
\text { production } \\
\text { management }\end{array}$ & 53 & 1 \\
\hline 38 & $\begin{array}{l}\text { Tóth et al. } \\
(2019)\end{array}$ & $\begin{array}{l}\text { International } \\
\text { journal of } \\
\text { operations and }\end{array}$ & 53 & 2 \\
\hline
\end{tabular}


Devi \& Ganguly: Social Media in Operations and Supply Chain Management: A Systematic Literature Review to Explore the Future

\begin{tabular}{|c|c|c|c|c|}
\hline No. & Study & $\begin{array}{l}\text { Journal \& } \\
\text { proceedings }\end{array}$ & $\begin{array}{l}\mathrm{H} \\
\text { index }\end{array}$ & $\begin{array}{l}\text { Citation } \\
\text { no. }\end{array}$ \\
\hline & & $\begin{array}{l}\text { production } \\
\text { management }\end{array}$ & & \\
\hline 39 & $\begin{array}{l}\text { Zavala et al. } \\
(2019)\end{array}$ & $\begin{array}{l}\text { International } \\
\text { journal of } \\
\text { production } \\
\text { economics }\end{array}$ & 95 & 7 \\
\hline 40 & $\begin{array}{l}\text { Banerjee et al. } \\
(2019)\end{array}$ & $\begin{array}{l}\text { International } \\
\text { journal of } \\
\text { operations and } \\
\text { production } \\
\text { management }\end{array}$ & 53 & 3 \\
\hline 41 & $\begin{array}{l}\text { Choi et al. } \\
(2020)\end{array}$ & $\begin{array}{l}\text { Transportation } \\
\text { Research Part E: } \\
\text { Logistics and } \\
\text { Transportation } \\
\text { Review }\end{array}$ & 57 & 0 \\
\hline 42 & Cui et al. (2019) & $\begin{array}{l}\text { International } \\
\text { journal of } \\
\text { operations and } \\
\text { production } \\
\text { management }\end{array}$ & 53 & 0 \\
\hline 43 & $\begin{array}{l}\text { Giannakis et al. } \\
(2020)\end{array}$ & $\begin{array}{l}\text { Annals of } \\
\text { operations } \\
\text { research }\end{array}$ & 50 & 0 \\
\hline 44 & $\begin{array}{l}\text { Guo et al. } \\
(2020)\end{array}$ & $\begin{array}{l}\text { International } \\
\text { journal of } \\
\text { operations and } \\
\text { production } \\
\text { management }\end{array}$ & 53 & 0 \\
\hline 45 & Orji et al. (2020) & $\begin{array}{l}\text { International } \\
\text { journal of } \\
\text { production } \\
\text { research }\end{array}$ & 77 & 10 \\
\hline 46 & $\begin{array}{l}\text { Schmidt et al. } \\
(2020)\end{array}$ & $\begin{array}{l}\text { Journal of } \\
\text { operations } \\
\text { management }\end{array}$ & 50 & 3 \\
\hline 47 & $\begin{array}{l}\text { Wang et al. } \\
(2020)\end{array}$ & $\begin{array}{l}\text { International } \\
\text { journal of } \\
\text { operations and } \\
\text { production } \\
\text { management }\end{array}$ & 53 & 1 \\
\hline 48 & $\begin{array}{l}\text { Yoo et al. } \\
(2020)\end{array}$ & $\begin{array}{l}\text { Production and } \\
\text { Operations } \\
\text { Management }\end{array}$ & 45 & 0 \\
\hline 49 & $\begin{array}{l}\text { Zhan et al. } \\
(2020)\end{array}$ & $\begin{array}{l}\text { International } \\
\text { journal of } \\
\text { operations and } \\
\text { production } \\
\text { management }\end{array}$ & 53 & 1 \\
\hline 50 & $\begin{array}{l}\text { Elghannam et } \\
\text { al. (2020) }\end{array}$ & Foods & - & 5 \\
\hline 51 & $\begin{array}{l}\text { Serbetcioglu } \\
\text { and Gocer } \\
(2020)\end{array}$ & $\begin{array}{l}\text { Journal of business } \\
\text { and industrial } \\
\text { marketing }\end{array}$ & 36 & 0 \\
\hline
\end{tabular}

Table A2. Quality Score of selected research articles

\begin{tabular}{|l|l|l|l|l|l|l|}
\hline Studies & QE1 & QE2 & QE3 & QE4 & QE5 & $\begin{array}{l}\text { Total } \\
\text { score }\end{array}$ \\
\hline O'leary (2011) & 1.5 & 2 & 1 & 1.5 & 0 & 6 \\
\hline O'leary (2012) & 1.5 & 1 & 1 & 1 & 0 & 4.5 \\
\hline $\begin{array}{l}\text { Markova et al. } \\
\text { (2013) }\end{array}$ & 1.5 & 1 & 1 & 1 & 0 & 4.5 \\
\hline $\begin{array}{l}\text { Swain and Cao } \\
\text { (2013) }\end{array}$ & 2 & 2 & 2 & 1 & 0 & 7 \\
\hline
\end{tabular}

\begin{tabular}{|c|c|c|c|c|c|c|}
\hline $\begin{array}{l}\text { Rapp et al. } \\
(2013)\end{array}$ & 2 & 1 & 1 & 2 & 0 & 6 \\
\hline $\begin{array}{l}\text { Calefato et al. } \\
\text { (2014) }\end{array}$ & 2 & 1 & 2 & 1 & 0 & 6 \\
\hline $\begin{array}{l}\text { Fisher et al. } \\
(2014)\end{array}$ & 1.5 & 2 & 2 & 1 & 0 & 6.5 \\
\hline Sigala (2014) & 1.5 & 1.5 & 1 & 2 & 0 & 6 \\
\hline $\begin{array}{l}\text { Sianipar and } \\
\text { Yudoko (2014) }\end{array}$ & 1.5 & 1 & 2 & 1 & 0 & 5.5 \\
\hline Chae (2015) & 2 & 1 & 1 & 2 & 1 & 7 \\
\hline $\begin{array}{l}\text { Song et al. } \\
(2015)\end{array}$ & 2 & 2 & 2 & 1 & 0 & 7 \\
\hline $\begin{array}{l}\text { Lam et al. } \\
(2016)\end{array}$ & 2 & 1 & 2 & 1.5 & 1 & 7.5 \\
\hline $\begin{array}{l}\text { Yoo et al. } \\
(2016)\end{array}$ & 2 & 2 & 2 & 2 & 0 & 8 \\
\hline $\begin{array}{l}\text { Fan and Nui } \\
(2016)\end{array}$ & 1.5 & 2 & 2 & 1.5 & 0 & 7 \\
\hline $\begin{array}{l}\text { Irani et al. } \\
(2017)\end{array}$ & 1.5 & 1 & 1 & 1 & 0 & 4.5 \\
\hline $\begin{array}{l}\text { Chan et al. } \\
\text { (2017) }\end{array}$ & 2 & 1 & 2 & 1.5 & 2 & 8.5 \\
\hline $\begin{array}{l}\text { Eftekhar et al. } \\
\text { (2017) }\end{array}$ & 2 & 2 & 1 & 1.5 & 1 & 7.5 \\
\hline Grant (2017) & 1.5 & 1 & 2 & 1 & 0 & 5.5 \\
\hline $\begin{array}{l}\text { Jiang et al. } \\
(2017)\end{array}$ & 2 & 1 & 2 & 1.5 & 0 & 6.5 \\
\hline $\begin{array}{l}\text { Ramanathan et } \\
\text { al. (2017) }\end{array}$ & 2 & 2 & 2 & 2 & 0 & 8 \\
\hline Cui et al. (2018) & 2 & 1 & 2 & 1.5 & 0 & 6.5 \\
\hline $\begin{array}{l}\text { Cheng et al. } \\
(2018)\end{array}$ & 2 & 2 & 2 & 1 & 2 & 9 \\
\hline $\begin{array}{l}\text { Elghannam et } \\
\text { al. (2018) }\end{array}$ & 2 & 1.5 & 2 & 1 & 0 & 6.5 \\
\hline Lin et al. (2018) & 2 & 0 & 1 & 2 & 1 & 6 \\
\hline $\begin{array}{l}\text { Mohammad et } \\
\text { al. (2018) }\end{array}$ & 1.5 & 0 & 2 & 1 & 1 & 5.5 \\
\hline $\begin{array}{l}\text { Nasrollahi } \\
(2018)\end{array}$ & 2 & 0 & 2 & 1 & 0 & 5 \\
\hline $\begin{array}{l}\text { Denktaş-Şakar } \\
\text { and Sürücü } \\
(2018)\end{array}$ & 2 & 2 & 1 & 1 & 0 & 5.5 \\
\hline $\begin{array}{l}\text { Yan and } \\
\text { Martinez (2019) }\end{array}$ & 1.5 & 1 & 2 & 1 & 1 & 6.5 \\
\hline $\begin{array}{l}\text { Ampountolas et } \\
\text { al. (2019) }\end{array}$ & 2 & 2 & 2 & 0 & 0 & 6 \\
\hline $\begin{array}{l}\text { Kanagarajoo et } \\
\text { al. (2019) }\end{array}$ & 1.5 & 2 & 2 & 1 & 0 & 6.5 \\
\hline $\begin{array}{l}\text { Fesseha et al. } \\
(2019)\end{array}$ & 2 & 1.5 & 1 & 1 & 0 & 5.5 \\
\hline $\begin{array}{l}\text { Wamba et al. } \\
(2019)\end{array}$ & 1.5 & 2 & 2 & 1.5 & 1 & 8 \\
\hline $\begin{array}{l}\text { T seng et al. } \\
(2019)\end{array}$ & 2 & 1.5 & 2 & 2 & 0 & 7.5 \\
\hline $\begin{array}{l}\text { Alkhatib et al. } \\
\text { (2019) }\end{array}$ & 2 & 1 & 2 & 2 & 1 & 8 \\
\hline Liu et al. (2019) & 2 & 1 & 1 & 1.5 & 0 & 5.5 \\
\hline $\begin{array}{l}\text { Nilsang et al. } \\
(2019)\end{array}$ & 2 & 1 & 2 & 1.5 & 0 & 6.5 \\
\hline $\begin{array}{l}\text { Tang et al. } \\
\text { (2019) }\end{array}$ & 2 & 2 & 2 & 1.5 & 0 & 7.5 \\
\hline $\begin{array}{l}\text { Tóth et al. } \\
(2019)\end{array}$ & 1.5 & 2 & 2 & 1.5 & 0 & 7 \\
\hline $\begin{array}{l}\text { Zavala et al. } \\
(2019)\end{array}$ & 2 & 1 & 2 & 2 & 0 & 7 \\
\hline
\end{tabular}




\begin{tabular}{|l|l|l|l|l|l|l|}
\hline $\begin{array}{l}\text { Banerjee et al. } \\
(2019)\end{array}$ & 2 & 1 & 2 & 1.5 & 1 & 7.5 \\
\hline $\begin{array}{l}\text { Choi et al. } \\
(2020)\end{array}$ & 2 & 1 & 2 & 1.5 & 0 & 6.5 \\
\hline Cui et al. (2019) & 2 & 2 & 2 & 1.5 & 1 & 8.5 \\
\hline $\begin{array}{l}\text { Giannakis et al. } \\
(2020)\end{array}$ & 1.5 & 2 & 2 & 1.5 & 0 & 7 \\
\hline $\begin{array}{l}\text { Guo et al. } \\
(2020)\end{array}$ & 2 & 1 & 2 & 1.5 & 1 & 7.5 \\
\hline $\begin{array}{l}\text { Orji et al. } \\
(2020)\end{array}$ & 2 & 1 & 2 & 1.5 & 1 & 7.5 \\
\hline $\begin{array}{l}\text { Schmidt et al. } \\
(2020)\end{array}$ & 2 & 2 & 2 & 1.5 & 1 & 8.5 \\
\hline
\end{tabular}

\begin{tabular}{|l|l|l|l|l|l|l|}
\hline $\begin{array}{l}\text { Wang et al. } \\
(2020)\end{array}$ & 2 & 2 & 2 & 1.5 & 1 & 8.5 \\
\hline $\begin{array}{l}\text { Yoo et al. } \\
(2020)\end{array}$ & 2 & 2 & 2 & 1 & 1 & 8 \\
\hline $\begin{array}{l}\text { Zhan et al. } \\
(2020)\end{array}$ & 1.5 & 2 & 2 & 1.5 & 1 & 8 \\
\hline $\begin{array}{l}\text { Elghannam et } \\
\text { al. (2020) }\end{array}$ & 1.5 & 1.5 & 1 & 1 & 0 & 5 \\
\hline $\begin{array}{l}\text { Serbetcioglu } \\
\text { and Gocer } \\
(2020)\end{array}$ & 1.5 & 2 & 2 & 1 & 0 & 6.5 \\
\hline
\end{tabular}

Note: QE: Quality Evaluation

Yashoda Devi is a $\mathrm{PhD}$ scholar in the area of Operations Management and Decision Sciences at Indian Institute of Management, Kashipur. She has done her post-graduation in Textile Engineering and Management from National Institute of Technology, Jalandhar. Her areas of interest are supply chain management, disruption management, and Facility location.

Kunal K. Ganguly is a faculty in the area of Operations Management and Decision Sciences at Indian Institute of Management, Kashipur. He has done his B.Tech in Manufacturing Engineering from NIFFT, Ranchi, MBA from IIT Kharagpur and $\mathrm{PhD}$ from IIT Kharagpur. He has more than six years of experience in industry in various fields of Operation, Quality Control and Training. For the past thirteen years he is associated with academics. He has worked as faculty with IMT Ghaziabad and KIIT School of management, Bhubaneswar for nine years. He has got publications in many reputed international journals. His areas of interest are Supply Chain management, Risk Management and Total Quality management. 